Article

\title{
The Introduction of Insect Meal into Fish Diet: The First Economic Analysis on European Sea Bass Farming
}

\author{
Brunella Arru $^{1, *}$, Roberto Furesi ${ }^{1}$, Laura Gasco ${ }^{2} \mathbb{D}$, Fabio A. Madau ${ }^{1, * \mathbb{C}}$ and Pietro Pulina ${ }^{1}$ \\ 1 Department of Agriculture-University of Sassari, 07100 Sassari (SS), Italy; rfuresi@uniss.it (R.F.); \\ ppulina@uniss.it (P.P.) \\ 2 Department of Agricultural, Forestry and Food Sciences, University of Turin, 10095 Grugliasco (To), Italy; \\ laura.gasco@unito.it \\ * Correspondence: brarru@uniss.it (B.A.); famadau@uniss.it (F.A.M.); Tel.: +39-07-922-9259 (B.A.); \\ +39-07-922-9258 (F.A.M.)
}

Received: 21 January 2019; Accepted: 14 March 2019; Published: 21 March 2019

check for updates

\begin{abstract}
The economic and environmental sustainability of aquaculture depends significantly on the nature and quality of the fish feed used. One of the main criticisms of aquaculture is the need to use significant amounts of fish meal, and other marine protein sources, in such feed. Unfortunately, the availability of the oceanic resources, typically used to produce fish feed, cannot be utilized indefinitely to cover the worldwide feed demand caused by ever-increasing aquaculture production. In light of these considerations, this study estimates how aquaculture farm economic outcomes can change by introducing insect meal into the diet of cultivated fish. Several possible economic effects are simulated, based on various scenarios, with different percentages of insect flour in the feed and varying meal prices using a case study of a specialized off-shore sea bass farm in Italy. The findings indicate that the introduction of insect meal-composed of Tenebrio molitor-would increase feeding costs due to the high market prices of this flour and its less convenient feed conversion ratio than that of fish meal. Therefore, the expected environmental benefits of using this highly promising insect meal in fish feed do not align with the current economic interests of the aquaculture industry. To our knowledge, this is the first study to investigate this theme, and it must be noted that our findings cannot be generalized widely because a specific case study was used. Nevertheless, our findings suggest that efforts should be made-at least at the farm level一to find profitable ways to encourage the introduction of this attractive alternative to guarantee both economic and environmental sustainability in the near future.
\end{abstract}

Keywords: aquaculture; economic sustainability; small-scale fish farming

\section{Introduction}

Fish is a primary source of protein, essential fats, minerals, and vitamins, and the demand for fish is rising dramatically due to population growth [1]. As a result, in order to keep the per capita consumption unchanged, the demand for fish will increase by more than 20 million tons over the next few decades [2].

Thus, it is clear that wild fishing alone cannot satisfy the demand for fish without jeopardizing the conservation of marine resources and the sustainability of fisheries; both objectives promoted by most international and national institutions [1,3]. In fact, fisheries are progressively causing the decline of the availability of wild aquatic organisms, and the need to limit the overexploitation of fish stocks is a crucial, global issue. 
One solution for overcoming this problem and responding to the demand for fish is aquaculture, which is the practice of rearing, growing, or producing sea or freshwater organisms, thus reducing the overexploitation and misuse of the seas [1]. Today, aquaculture is the fastest growing food industry in the world [1]. According to the FAO, about 600 species are currently grown via aquaculture, the production volume amounts to more than 100 million tons, and the global value of production is about $\$ 170$ billion dollars, which corresponds to about $45 \%$ of the global fish production; an amount predicted to grow by $62 \%$ by 2030 [1].

In light of these perspectives, there has been an increase in the number of studies focused on the economic and environmental sustainability of aquaculture [4]. Among other concerns, it is a fact that the sustainability of aquaculture depends highly on the nature and quality of the feed used in aquafarms, because such feed contributes significantly to fish health and is a possible source of water and ecosystem pollution.

From an environmental viewpoint, the huge amount of fish meal (FM), fish oil, and other marine protein sources in fish feed is a pivotal problem [5,6], because there are not enough currently existing oceanic resources to produce the fish feed needed to satisfy the continuously increasing global aquaculture production [6]. From an economic viewpoint, the increase of the global feed price, mainly caused by the increasing fish demand, has made the cost of feed a primary, industry-wide concern [1]. Against this background, researchers have been called upon to find-at the sector and farm level-alternative solutions to limit the environmental burden and to keep farming costs down, because these two sustainability dimensions of the industry cannot be assessed separately, but rather must be addressed in synergy.

To this end, research focused on the macro-level has aimed to design systems that facilitate the achievement of environmental objectives (e.g., the reduction of the consumption of resources and the environmental impact of aquaculture; the promotion of optimal development, growth, and reproduction of fish; the replacement of FM in feed with sustainable alternatives) that have a positive impact on productivity, profitability, and the long-term sustainability of aquaculture production [1,6-8]. Along the same lines, the few studies focusing on the micro-level have analyzed the ability of individual companies to be economically sustainable and to achieve a competitive business position with stable returns over time [9]. These objectives, however, have been undermined by the feeding cost-estimated to constitute $40 \%-70 \%$ of the total cost of production [10] and $75 \%-85 \%$ of the variable costs [11-13] — which has limited the sustainable development of this industry. Indeed, the rise in feed prices does not result in comparable rises in the final market prices of aquaculture products due to steep horizontal and vertical competition [14], having massive economic consequences on individual businesses [13].

The main proposed alternative to FM is soybean meal, which has been introduced into fish farms. However, soybean meal has been criticized for generating high land-use competition and significant environmental deterioration $[6,8]$, as well as for containing anti-nutritional factors that inflame the digestive tract of fish, having low palatability, and contributing few sulfur (methionine and cysteine)-comprising amino acids.

On the other hand, a plethora of scientific data demonstrates that insects represent a valid substitute for FM, fish oil, and conventional protein meals. In feed trials, insects have been tested as is and in a processed form, and the results have depended on the insect species used, the level of processing, and the level of inclusion in the fish feed. Insect-derived products are characterized by a high protein content (ranging from $45 \%$ to $70 \%$ ), a good essential amino acid profile, and good lipid content, which varies from $8 \%$ to $35 \%$, depending on the lipid extraction process [6].

The European Commission recognized the aforementioned environmental and economic sustainability issues in the aquaculture industry by enacting Regulation $893 / 2017$, which permits the use of seven insect species in fish feed. Among the permitted species, the most promising are the yellow mealworm (Tenebrio molitor), the black soldier fly (Hermetia illucens), and the common house fly (Musca domestica). Their high potential as alternative feed ingredients is related to the potential of 
mass rearing them on byproducts, promoting the concept of a circular economy and zero waste [15]. Belforti et al. [16] found that including T. molitor (TM) in rainbow trout feed up to a proportion of $50 \%$ has no effect on weight gain. Other authors tested the substitution of FM with TM in the diets of different fish species (e.g., European sea bass, common catfish, tilapia) [17-20], and the findings suggest that TM can partially replace FM in the diet of many species [20].

From a market perspective, the insect business is a fast-growing sector, and several such companies or startups [21] have been founded in Europe (e.g., Ynsect, Protix, Mutatec, Hermetia Baruth GMBH) and outside Europe (e.g., Entofood, Agriprotein, Enviroflight, Enterra). So far, the Insect Platform for Insects as Food and Feed has 46 members [22].

Because of its inherent characteristics, insect meal could one day spark the intensification of aquaculture production and be the driving force for the growth of individual companies, reducing the cost of feed, even if the current market prices of insect meal are generally higher than those of FM (the Brabant Development Company [23] projects that the price of insect proteins will become competitive with that of FM by 2023).

In light of these considerations, this study estimates how farm economic outcomes can change by introducing insect meal into fish feed. The possible economic effects were simulated based on various scenarios with different percentages of insect meal-composed exclusively of Tenebrio molitor-introduced into fish feed and varying possible meal prices. A case study of a specialized, off-shore European sea bass (Dicentrarchus labrax) farm in Italy was used to simulate the possible economic effects. It must be noted that sea bass is "a major species culture in Mediterranean region" [17] (p. 35) with about 160,000 tons of production, primarily from the Mediterranean, in 2015 [24].

A case study approach was chosen because of the lack of empirical data about the real introduction of insect meal into fish feed, and the fact that only technical data are collected by some experimental results. First, balance sheet analysis was carried out to describe the baseline scenario (only FM use), followed by an assessment of the possible main economic effects derived from introducing Tenebrio molitor meal into the European sea bass diet.

This paper confirms previous studies on the cost structure of aquaculture enterprises and offers important information regarding the possible conflicts between the need for environmentally sustainable production - in terms of limiting the overexploitation of marine resources-and the need to ensure an aquafarm's profitability. Thus, our study represents the first empirical attempt to investigate the economic effects of substituting FM with insect meal in fish feed.

Section 2 presents a literature review on the use of TM as an insect meal for fish and the cost structure of aquafarms. Section 3 describes our research methodology and the case study. Section 4 presents the results. The last section provides our conclusions and explains the implications of this study on industry practices, policymakers, and academia, as well as suggested avenues for further research.

\section{Literature Review}

Human efforts to produce ever-increasing amounts of food impact the environment, placing extreme stress on ecosystems. One serious consequence of the over-exploitation of ecosystems is the threat posed to fish production. Compounded by the continual growth of the world's population, a global protein shortage is foreseen [25]. For these reasons, the increasing number of people require that future fish production be not only high yielding, but also sustainable.

Fish require quite a high quantity of high-quality protein. For this reason, FM, due to its optimal protein and amino acid composition, was, until now, the best protein source for fish feed [6], together with soybean meal. However, this formula does not meet specific criteria that go beyond the nutritional perspective, "such as regular availability in quantity, economic value, non-competition with resources for humans (water, land, or even the same source, as occurs with soy) and environmental sustainability" [18] (p. 1). Indeed, the fish industry's sustainability is under threat from the rapid rise of 
aquaculture and the consequent increase in demand for FM, which is a limited resource [26]. Plant proteins are a possible solution, even though they have several limitations, such as anti-nutritional factors, the high levels of fiber and non-starch polysaccharides, inadequate fatty acid and amino acid profiles [27], low palatability, and the impairment of the integrity of fish intestinal enterocytes [6,26,27].

Insect meal has great potential to overcome the aquaculture sector's problems. First of all, insects are part of the natural diet of freshwater and marine fish [10,28], especially in the juvenile stage [6]. Insects are also an excellent source of protein, with an average dry matter (DM) basis that varies between $45 \%$ and $75 \%$ [6] and a well-balanced essential amino acid profile, as well as a source of several other high-quality components, including appropriate levels of minerals (such as potassium, calcium, iron, magnesium, and selenium) and several vitamins [10].

Insect meal is also a highly environmentally friendly source of nutrients [29], in accordance with Goal 14 of the Sustainable Development Goals and the 2015 Chart of Milan.

Among the different candidate species to produce insect meal for aquaculture, Tenebrio molitor (TM) — commonly known as yellow mealworm-is considered to be one of the most promising protein sources for replacing FM in fish feed [6,20]. This is because (i) TM is a worldwide distributed coleopter belonging to the Tenebrionidae family [30]; (ii) the larvae of TM are rich in crude protein $(53.2 \%)$ and fat (34.5\%) [31], have an adequate amino acid profile, and are easy to breed and feed [32]; (iii) $\mathrm{TM}$ is rich in zinc, selenium, riboflavin, biotin, pantothenic acid, folic acid, chitin and antimicrobial peptide, isoleucine, leucine, lysine, and unsaturated fatty acids [32-35]; and (iv) TM is "currently produced on relatively large industrial scales as insectivorous pet food, fishing bait and even for human consumption" [36] (p. 215). Therefore, in light of its particular features and the feasibility of the mass production of TM, it is a convenient and appropriate substitute for FM in fish feed [36].

Based on the evidence above and given that the European Union (EU) suffers from significant protein deficiency and imports over $70 \%$ of its consumed proteins (European Parliament motion 2010/2111(INI)), the EU Commission recently regulated the use of insect-derived proteins in animal diets (Commission Regulation (EU) 2017/893).

However, today, despite the prominent thinking about the potential key role of insect meal in protein production in terms of constant quantities, high quality, the stability of supply and price [18], and price reduction [37], the current price of insect meal is still not competitive with other protein sources [38]. Additionally, given the current cost structure of the aquaculture farm, as reported above, the most urgent challenge for the aquaculture sector is the cost of FM and fish oil. Moreover, economically sustainable aquaculture development is slowing down due to the price of fish feed, the continuous price increase of which is not reflected in the final market price of the cultivated fish. All these factors, together with the need for ever-increasing investments in fixed capital, significantly affect the economic feasibility of the individual fish farm $[13,14]$.

\section{Case Study}

A case study is a methodology that applies a multidimensional approach to analyze a phenomenon in depth within its real-life context [39]. This method is frequently employed in business research, giving a voice to successful business experiences, providing theoretical objectives, and suggesting concrete routes of action. Moreover, even though such qualitative research prioritizes the particulars of a case rather than its representativeness $[40,41]$ and makes the generalization of the results difficult, it provides useful theoretical propositions that can be tested in larger quantitative research projects.

In this work, the qualitative case study method $[39,42]$ is useful, because this research is one of the first to inquire into the problem of the profitability of aquaculture enterprises and aims to fill the gap in the literature about the economic effects related to the possible use of insect meal.

\subsection{Data Collection}

Here, we analyzed a small-sized, off-shore fish farm located in Sardinia, Italy. The farm was set up in the early 2000s and specializes in the production of sea bass. The fish production of this 
farm, similar to any other aquaculture farm in the territory, is exclusively based on FM as the fish feed. Because of this, this farm does not provide us with real data to precisely estimate the economic effects derived from the use of other meals, such as insect meal, which is the matter in question here. However, given the farmer/manager's inclinations to introduce innovative feed to potentially reduce costs and improve product quality, this fish farm was considered suitable for our research goals.

The case study information was gathered in 2017, through both a semi-structured interview conducted with the farm director and the analysis of the budget and internal documentation relating both to the variable and fixed costs of the farm. These two connected investigation tools described the status quo of the sea bass farm, particularly regarding feeding costs and their contribution to the overall costs. Starting from this status quo condition, a simulation was performed to evaluate the main economic effects associated with the introduction of insects into fish feed, based on different economic scenarios and technical solutions.

\subsection{Sea Bass Production and Feeding Cost}

The primary information about the sea bass production process and plant dimension of the farm is shown in Table 1. The specimens grow in two cages, which after an 18-month cycle, produces about 260,000 sea basses, amounting to an annual output of approximately 175,000 specimens. Given that the commercial size of a specimen corresponds, on average, to $0.40 \mathrm{~kg}$, the yearly production is about 66 tons, which is mostly intended for the domestic market, especially to big retailers. The price at the farm gate varies from $€ 5.5$ to $€ 6.5 / \mathrm{kg}$.

Table 1. Main technical characteristics of the fish farm analyzed regarding the sea bass production process.

\begin{tabular}{ccccccccc}
\hline Cages, $N$ & $\begin{array}{c}\text { Specimen } \\
\text { (by Cage), } N\end{array}$ & $\begin{array}{c}\text { Specimen } \\
\text { (total), } N\end{array}$ & $\begin{array}{c}\text { Biological } \\
\text { Cycle }\end{array}$ & $\begin{array}{c}\text { Size of } \\
\text { Marketable } \\
\text { Sea Bass }\end{array}$ & $\begin{array}{c}\text { Weight } \\
\text { Gain } \\
\text { (WG) }\end{array}$ & $\begin{array}{c}\text { Feed for } \\
\text { Specimen } \\
\text { (FS) }\end{array}$ & $\begin{array}{c}\text { Feed } \\
\text { Conversion } \\
\text { Ratio } \\
\text { (FCR) }\end{array}$ & $\begin{array}{c}\text { Feed } \\
\text { Distributed } \\
\text { (total) } \\
\text { (FD) }\end{array}$ \\
\hline 2 & 130,000 & 260,000 & 18 months & $0.40 \mathrm{~kg}$ & $0.38 \mathrm{~kg}$ & $0.76 \mathrm{~kg}$ & $2.00(2: 1)$ & $197,600 \mathrm{~kg}$ \\
\hline
\end{tabular}

As mentioned above, the farm exclusively uses FM as a protein source. The sea bass eats a meal formula composed of about 50\% FM (the percentage depends on the type of formulation, which is determined by the age of each specimen). The feed conversion ratio (FCR; i.e., DM basis intake $(\mathrm{kg}) /$ live mass gain $(\mathrm{kg})$ ) amounts to $2: 1$. The weight of a sea bass juvenile is about $0.02 \mathrm{~g}$, with an average weight gain of $0.38 \mathrm{~kg}$, resulting in $0.76 \mathrm{~kg}$ of feed for the specimen. The average price paid for the feed formula is $€ 1.85 / \mathrm{kg}$. Thus, the cost for the fish feed for the length of the biological cycle is about $€ 366,000$, and the annual feeding cost is close to $€ 244,000$.

\subsection{Balance Sheet Analysis}

The balance sheet makes up the basis of the estimation of the cost structure of the sea bass farm, from which the proportion of the feeding cost to the total cost and the profit is calculated. Table 2 reports the balance items and their descriptions.

Some clarifications of these items are provided below.

(i) All the fish farm revenues are generated by the value of the marketable sea bass produced.

(ii) Capital mainly consists of the two cages for the livestock, the machinery for feeding, and the headquarters, whereas the boat used for movement is annually rented. This item is also included in the capital interests.

(iii) The labor-both manual and directive—-is chiefly done by permanent employees, including the farmer who works as an employee, even though, especially during the harvesting of the specimens, there may also be seasonal workers. 
Table 2. Balance sheet items considered and their description.

\begin{tabular}{|c|c|c|}
\hline & Item & Description \\
\hline Revenues & Value of Production (TR) & Value of Sea Basses Produced $(€)$ \\
\hline \multirow{8}{*}{$\begin{array}{c}\text { Variable } \\
\text { Costs }\end{array}$} & Cost for energy and water (EW) & Cost for the use of energy and water $(€)$ \\
\hline & Cost for fuel (FU) & Cost for the use of fuel $(€)$ \\
\hline & Rent for boat (RB) & Cost for the use of boat $(€)$ \\
\hline & Cost of raw materials: livestock cost (LC) & $\begin{array}{c}\text { Cost for purchasing juveniles and other raw } \\
\text { materials for livestock }(€)\end{array}$ \\
\hline & Cost of raw materials: feeding cost (FC) & Cost for feed $(€)$ \\
\hline & Salaries (SA) & Cost for salaries of seasonal workers $(€)$ \\
\hline & Other variable costs (OVC) & Other variable costs $(€)$ \\
\hline & Interests (I) & Interests on variable costs $(€)$ for 18 months \\
\hline \multirow{2}{*}{$\begin{array}{c}\text { Fixed } \\
\text { Cost }\end{array}$} & Wages and salaries (WS) & $\begin{array}{c}\text { Cost for wage and salary for permanent } \\
\text { employees }(€)\end{array}$ \\
\hline & $\begin{array}{c}\text { Depreciation of capital (DC) } \\
\text { Taxes (TX) }\end{array}$ & $\begin{array}{l}\text { Annual quote of depreciation of capital }(€) \\
\text { Cost for taxes }(€)\end{array}$ \\
\hline
\end{tabular}

\subsection{Simulations on Use of Insect Meal}

The simulation of the effect of using TM in the sea bass diet on the structure of the company costs was made based upon the possible outcomes derived from this inclusion. Its starting point was based on some recent works in the scientific literature. In particular, this analysis was based on the empirical evidence data of Gasco et al. [17], who conducted a study on the effects of replacing different percentages of FM with TM in the diet of the European sea bass. According to the findings of Gasco et al. [17], the sea bass registers a feed conversion ratio (FCR) that differs on the basis of the replacement percentage of FM with TM, i.e., a FCR equal to $0.90,0.91$, and 0.99 in the $0 \%, 25 \%$, and $50 \%$ substitution scenarios, respectively.

The experimental trials were realized by replacing FM (which, in the status quo scenario, is equal to $50 \%$ of the whole formula) with TM meal as the feed basis in five increasing levels: $5 \%, 10 \%, 15 \%, 25 \%$, and $50 \%$, respectively. The FCR in the simulations was decreased based on the progression reported in Gasco et al. [17] and was applied at a starting point of 2.00 in the status quo scenario (see Table 1).

\section{Results}

The findings of the balance sheet analysis are shown in Table 3 and are presented from two perspectives: budget year and biological cycle length. The analysis demonstrates that sea bass production is profitable. With regard to this, it is important to point out that the value obtained by the fish farmer from business activity is higher than the farm profit, because the farmer, also being a worker, receives a salary in addition to profit. Nevertheless, the analysis demonstrates the extremely high feeding cost, which corresponds to more than $63 \%$ of the total cost. This data is in line with previous studies on the cost structure of fish farms [10-13,43,44], in which over $60 \%$ of farm costs are feeding costs.

These findings underline the urgent need to adopt measures to limit the magnitude and incidence of this item.

Starting from these results, and as reported above, estimates were computed considering the change in the feeding cost caused by the increasing the levels of TM meal in the fish feed and the different prices for purchasing this alternative meal. Table 4 shows the findings of the simulations that used the level of production of the status quo scenario $(104,000 \mathrm{~kg})$ as a reference point.

Some clarifications about the FM and TM prices are provided below. 
(i) Usually, aquaculture enterprises do not buy pure FM, instead purchasing feed formulas containing FM percentages. These feed formulas vary depending on both the feed mill supplying the farm and the fish growth stage. The analyzed company does not differ from this practice, and the price of the formula indicated in Table $4(1.85 € / \mathrm{kg})$ is an average price paid for the entire biological cycle/budget year production;

(ii) Based on the average market price, the price of fish meal is around $1.48 € / \mathrm{kg}$, plus VAT;

(iii) We hypothesized two TM flour price scenarios that may occur in the near future given the forecasts of price decrease: $5.00 € / \mathrm{kg}$ and $2.50 € / \mathrm{kg}$. These prices represent one-third and one-sixth of the current TM price as indicated by the Brabant Development Company [23]. Compared with the current scenario, characterized by higher TM prices than FM prices, we adopted a precautionary approach, setting more affordable levels of price for fish farms.

Table 3. Balance sheet analysis results.

\begin{tabular}{|c|c|c|c|c|}
\hline & Item & $\begin{array}{c}\text { Biological Cycle } \\
\text { (18 months) }\end{array}$ & $\begin{array}{l}\text { Budget Year } \\
\text { (12 months) }\end{array}$ & $\begin{array}{c}\% \text { of Total } \\
\text { Cost }\end{array}$ \\
\hline \multirow{3}{*}{ Revenues } & Total & 613,600 & 411,430 & \\
\hline & Quantity (kg) & 104,000 & 69,700 & \\
\hline & Average price $(€ / \mathrm{kg})$ & 5.90 & 5.90 & \\
\hline \multirow{9}{*}{ Variable Costs } & Total & 497,644 & 333,405 & $82.8 \%$ \\
\hline & Raw materials: feeding cost & 365,560 & 244,925 & $60.8 \%$ \\
\hline & Raw materials: livestock cost & 70,070 & 46,947 & $11.7 \%$ \\
\hline & Salaries & 15,035 & 10,073 & $2.5 \%$ \\
\hline & Fuel & 5346 & 3582 & $0.9 \%$ \\
\hline & Energy and water & 3505 & 2348 & $0.6 \%$ \\
\hline & Rent of boat & 11,880 & 7960 & $2.0 \%$ \\
\hline & Other variable costs & 4613 & 3091 & $0.8 \%$ \\
\hline & Interests & 21,635 & 14.495 & $3.6 \%$ \\
\hline \multirow{4}{*}{ Fixed Cost } & Total & 103,218 & 69,156 & $17.2 \%$ \\
\hline & Wages and salaries & 60,618 & 40,614 & $10.1 \%$ \\
\hline & Depreciation of capital & 6300 & 4221 & $1.0 \%$ \\
\hline & Taxes & 36,300 & 24,321 & $6.0 \%$ \\
\hline Total Cost & & 600,862 & 402,577 & $100.0 \%$ \\
\hline Profit & & 12,738 & 8,535 & \\
\hline
\end{tabular}

Furthermore, it is necessary to make some clarifications regarding the Feed Conversion Ratio (FCR). The objective of feed mills is to process and produce feeds that optimize the use of the nutrients contained in them (e.g., raw materials with high digestibility, technological processes that increase digestibility, use of probiotics or prebiotics or other additives that allow fish to better use nutrients, etc.) with repercussions on growth and conversion rates (FCR). In this case under examination, the FCR detected by Gasco et al. [17] was used. Therefore, in the alternative scenarios, the FCR was estimated based on the values reported by Gasco et al. [17], i.e., the FCR would increase by $0.5 \%, 1 \%$, and $10 \%$ with the inclusion of TM meal at $15 \%, 25 \%$, and $50 \%$, respectively. Hence, the quantity of the meal tends to increase with the increasing percentage of TM meal in the fish feed.

Figure 1 shows the isoquant that describes the set of points at which the farm output quantity is produced while changing the amounts of the two types of meals. The isoquant curve is asymmetric, due to the tendency of the FCR to increase slowly before and more dramatically afterwards, implying that the total quantity of feed useful for producing $1 \mathrm{~kg}$ of sea bass would increase concurrently with the substitution of FM with TM. 


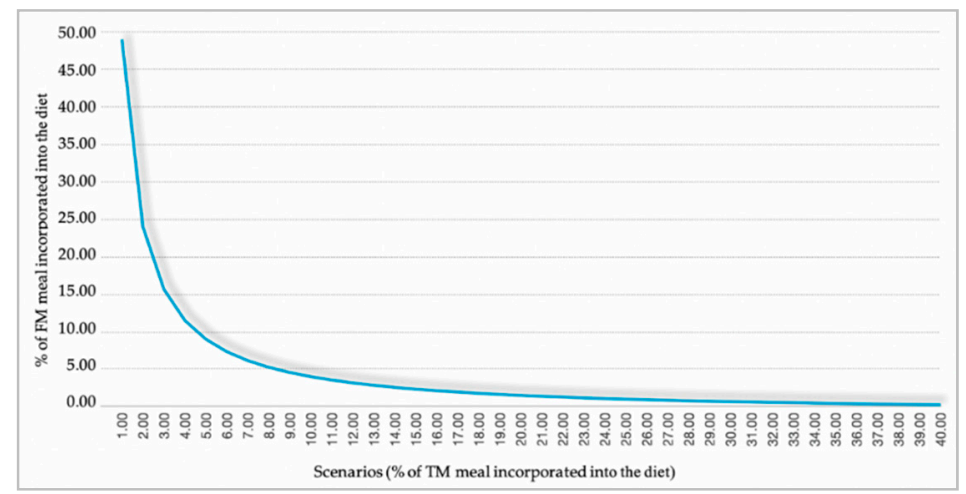

Figure 1. Estimated isoquant curve between fish meal (FM) and Tenebrio molitor (TM) meal.

As illustrated in Table 4, in the case of the complete replacement of FM with TM meal at a price of $€ 5.00$, the estimates suggest that the change in the feed cost compared with the status quo is close to $200 \%$, and the contribution of the feeding cost to the total cost tends to increase dramatically (to about $82.2 \%$ in the case of TM50\% and a TM price equal to $€ 5.00 / \mathrm{kg}$ ). These findings occur, because both the quantity of feed derived from the increased quota of TM meal and the market prices related to insect meal in the European market would tend to increase. In addition, three prices were calculated.

First, the buy price per $\mathrm{kg}$ of feed formula (BPF), considering the different scenarios of the price of TM meal and the replacement of FM with TM meal (third row of Table 4), was calculated.

Bearing in mind that the farm buys a feed that includes FM mixed with other compounds, the assumptions are as follows:

1. According to Gasco et al. [17], the percentage (in $\mathrm{kg}$ ) of the total of the other compounds (TOC) of the feed formula comprising the total formula (reference value of $1 \mathrm{~kg}$ ) remains unchanged in all the scenarios.

2. The percentage (in $\mathrm{kg}$ ) of the TOC is equal to $50 \%$ of the total feed formula.

3. The buy price of pure FM does not change, due to the changes in the scenarios.

4. The buy price of the TOC is estimated based on the rate of substitution between FM and TM (the weighted buy price of the two meals for their quantity). Therefore, in the TM0\% scenario, the buy price of $1 \mathrm{~kg}$ of pure FM equals the price of $1 \mathrm{~kg}$ of the entire feed formula, and in the TM $50 \%$ scenario, the buy price of pure TM meal equals the buy price of the total feed formula.

5. Given the objective of estimating the feeding cost incurred in the budget year (and in the entire biological cycle) by the buy price of the formula and that the formula's price changes according to the different stage of growth of the fish, the buy price of the formula is determined by an average price (see the Appendix A).

The estimates are reported in the third row of Table 4. The feed price (BP0) showed in Table 4 represents the price that the farm would have to pay to buy $1 \mathrm{~kg}$ of feed containing incremental quantities of TM meal in place of FM at a fixed price of $€ 1.85$. The data show that the buy price of the formula per $\mathrm{kg}$ would increase by $35 \%$ and $170 \%$ if the price of $\mathrm{TM}$ is $€ 2.50 / \mathrm{kg}$ and $€ 5.00 / \mathrm{kg}$, respectively, if FM is wholly substituted with TM meal (scenario TM50\%) (see also the $\Delta$ Feeding cost with respect to the status quo).

The other two calculated prices (last two rows of Table 4) refer to the prices that make the choice between FM and TM indifferent. These prices have been calculated both for the different percentages of substitutions and in the scenarios of the presence and absence of profit (see Appendix A).

The indifference buy price in the case of no change in profit $(\mathrm{BP} \pi)$ remains the same in the case of the substitution between the two meals at the $5 \%$ proportion, which tends to decline slightly up to a $25 \%$ substitution and drastically collapse in the scenario of total replacement of FM with TM meal. In the extreme scenario, to maintain the same profit as the TM0\% scenario, the formula price decreases by $9.2 \%$ (the formula price should decrease from $€ 1.85$ to $€ 1.68$ ). The exponential decrease is attributable 
to the worsening of the conversion rate recorded in the transition between the TM25\% and TM50\% scenarios (from $€ 2.02$ to $€ 2.20$ ).

Table 4. Results of simulations based on different technical and market scenarios.

\begin{tabular}{|c|c|c|c|c|c|c|c|}
\hline & Item & TM0\% & TM5\% & TM10\% & TM15\% & TM25\% & TM50\% \\
\hline \multirow{2}{*}{ Diet Composition (\%) } & Fish meal & 50.0 & 45.0 & 40.0 & 35.0 & 25.0 & 0.0 \\
\hline & TM meal & 0.0 & 5.0 & 10.0 & 15.0 & 25.0 & 50.0 \\
\hline \multirow{3}{*}{ Feed Used (kg) } & FCR & 2.00 & 2.00 & 2.00 & 2,01 & 2.02 & 2.20 \\
\hline & Feed/specimen & 0.76 & 0.76 & 0.76 & 0.76 & 0,77 & 0,84 \\
\hline & Total feed for cycle & 197,600 & 197,600 & 197,600 & 198,588 & 199,576 & 217,360 \\
\hline Feed Price $(€ /$ kg) & TM price $2=5.00 € / \mathrm{kg}$ & 1.85 & 2.17 & 2.48 & 2.80 & 3.43 & 5.00 \\
\hline \multirow{2}{*}{ Feeding Cost-18 Months Cycle (€) } & TM price $1=2.50 € / \mathrm{kg}$ & 365,560 & 378,404 & 391,248 & 406,112 & 434,078 & 543,400 \\
\hline & TM price $2=5.00 € / \mathrm{kg}$ & 365,560 & 427,804 & 490,048 & 555,053 & 683,548 & $1,086,800$ \\
\hline \multirow{2}{*}{ Feeding cost-Budget year $(€)$} & $\mathrm{TM}$ price $1=2.50 € / \mathrm{kg}$ & 243,707 & 252,269 & 260,832 & 270,742 & 289,385 & 362,267 \\
\hline & $\mathrm{TM}$ price $2=5.00 € / \mathrm{kg}$ & 243,707 & 285,203 & 326,699 & 370,036 & 455,699 & 724,533 \\
\hline Feeding Cost Impact on Total Cost & $\mathrm{TM}$ price $2=5.00 € / \mathrm{kg}$ & $60.8 \%$ & $64.5 \%$ & $67.6 \%$ & $70.2 \%$ & $74.4 \%$ & $82.2 \%$ \\
\hline \multicolumn{3}{|c|}{ Indifference Price TM (with Respect to Profit) ( $(€ / \mathrm{kg})$} & 1.85 & 1.85 & 1.82 & 1.80 & 1.68 \\
\hline \multicolumn{3}{|c|}{ Indifference Price TM (no profit) (€/kg) } & 2.47 & 2.16 & 2.02 & 1.94 & 1.74 \\
\hline
\end{tabular}

For the same reason, in the scenario of equality of revenue with the total costs (TMP0), the price of the TM meal undergoes a decrease to $€ 1.74$.

Figure 2 shows how the profits-calculated as the difference between revenues and total costs -vary by the increase in the meal prices for each scenario considered. In other words, it shows the feeding price that makes the choice indifferent (from a merely economic viewpoint) between the TM0\% scenario and the other five scenarios, respectively.

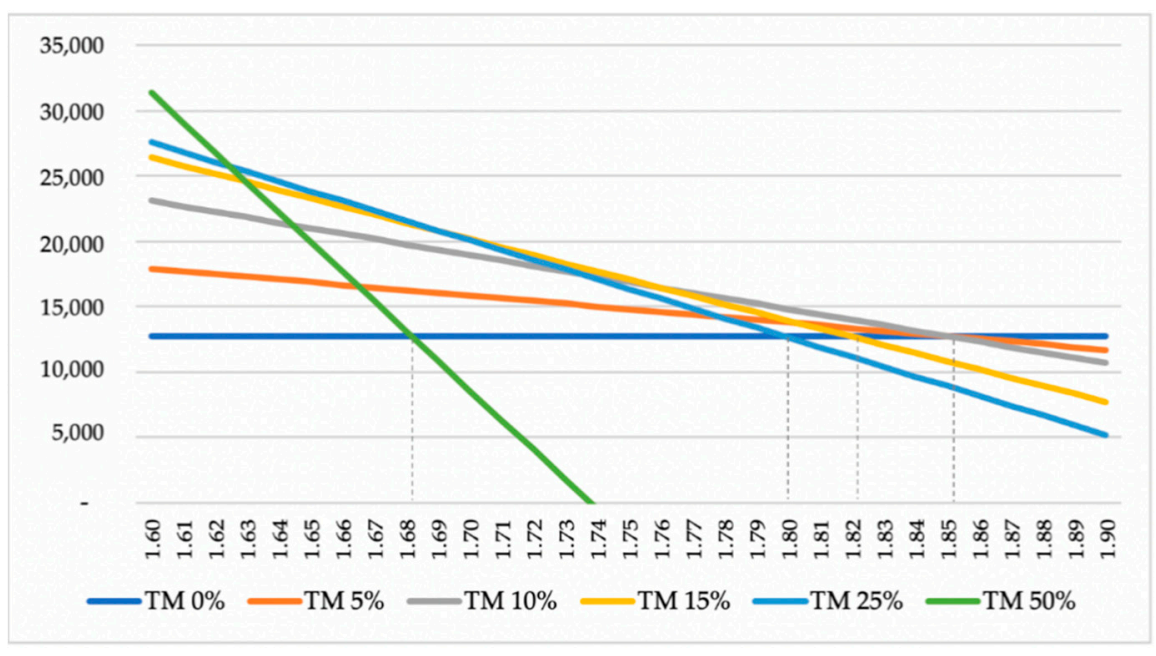

Figure 2. Indifference buy price (with respect to profit) $(€ / \mathrm{kg})$.

\section{Discussion and Conclusion}

Aquaculture contributes to almost half of the total fish production in the world, with a value of $\$ 232$ billion in 2016 [1]. This development-driven by the huge increase in the demand for fish due to the rise in population that cannot be satisfied by wild fish-demonstrates the clash between two important issues that are linked to each other. 
The first issue embodies the environmental concerns related to the sustainability of using FM and fish oil as the major component of the feed used in aquaculture [2,26]. Indeed, the supplies of these commodities are finite, but the expansion of aquaculture production has resulted in an increase in their consumption, which results in the overharvesting of the sea and the future destruction of such resources. As a consequence, there is an increasing demand for alternatives to stop the overexploitation and misuse of the seas, which have caused declining wild fish stocks [2,45].

The second issue encompasses serious concerns about the economic sustainability of aquaculture farming, i.e., its ability to be profitable in the long run. What emerged from the few studies focusing on the economic performance of aquaculture at the farm level [46] is the current critical state of the cost structure of aquaculture firms, in particular, due to high feeding costs, which have caused the failure of many such companies. Indeed, the increasing fish demand has resulted in the growing demand for feed, leading to a rapid rise in the price of fish feed [2]. Moreover, concerning sea bass production, this industry, which is often classed as capital intensive, today requires large initial investments and financial resources.

Economic and environmental dimensions of sustainability are interconnected as follows: (i) profit maximization should be pursued using resources efficiently and minimizing environmental impact, meaning that aquaculture should offer a more environmentally friendly fish production process than sea fishing; and (ii) achieving environmental goals depends on economic sustainability, which, in turn, depends on the ability of aquaculture enterprises to bear the burden of new eco-friendly production techniques or feed, which are often more expensive than those used in the present state of affairs.

In agreement with Nidumolu et al. [47], who argued that "there's no alternative to sustainable development" [47] (p. 57) and given the awareness that aquaculture has the potential to be environmentally sustainable, it is crucial to understand how to increase the economic performance of this type of production.

Insect meal is one of the potential solutions to the problems of aquaculture companies regarding the stability and reduction of feeding costs [18,37] and environment protection [48].

In light of these considerations, this study aimed to overcome the environmental and economic issues of the aquaculture sector, evaluating the economic viability of the introduction of insect meal into the sea bass diet, which is one of the most cultivated species in the Mediterranean.

To this end, first, the fish farm enterprise cost structure was analyzed, confirming the findings of previous studies [10-13], according to which feeding costs represent the main concern in the fish farm cost structure, especially with respect to small-scale farms.

Second, an estimation of the economic effects caused by TM inclusion in the sea bass diet was conducted. Being the first such empirical application in this field, the lack of previous empirical results regarding the cost effects of the introduction of insect meal into fish feed does not allow for a comparison of the current findings. However, an estimation of the economic consequences of such an innovative diet is pivotal to address the current problems in the aquaculture sector and suggest possible solutions for the near future.

Nevertheless, at present, insect meal is not a competitive protein source for use in aquaculture fish feed [38]. Indeed, according to the Brabant Development Company [23], the commercial price of TM flour is $15 € / \mathrm{kg}$ and the price of insect proteins will only become competitive with that of FM in 2023. One possible way to make this scenario feasible is to increase the scale of production in the insect industry, which could encourage an increase in the price competitiveness and production stability of insect feeds over other protein sources [22].

The findings obtained in the current study confirm the low competitiveness of TM as it stands today and demonstrate that profitability would decrease if insect meal were partially introduced into fish feed in today's market. The analysis estimated the effects on the cost structures of two price scenarios that might reflect the decreasing prospects of insect flour, i.e., one-third $(5 € / \mathrm{kg})$ and one-sixth $(2.50 € / \mathrm{kg})$ of the price indicated by the Brabant Development Company [23]. The findings 
showed that the replacement of 50\% FM with TM entails an increase in feed costs of $49 \%$ and $197 \%$ in the TM price $1(2.50 € / \mathrm{kg})$ and $2(5.00 € / \mathrm{kg})$ scenarios, respectively.

Given these results, we wanted to estimate the price of TM at which the choice between TM and FM for all percentages of replacement between the two flours becomes moot. This indifference price was calculated according to two scenarios: (i) the company records a profit (equal to $€ 613,600$ ), which is a price that naturally also reflects the company's ability to fetch a good price from its clients and therefore is a very specific price for the analyzed company; (ii) non-profit, in which the estimated price is less influenced by the ability of the entrepreneur to sell effectively the products in the market place. The findings show that the indifference price decreases as the percentage of FM replacement with TM increases due to the increase in the FCR. In the extreme scenario, the price of TM must be lower than that of FM by about $9 \%$, if we consider the profit of the company being analyzed, and lower by about $11 \%$ in the absence of profit.

This study suggests that the highly acclaimed introduction of insect meal into fish feed is currently not economically viable for small- to medium-sized aquaculture businesses. At present, insect flour cannot be considered to be an alternative for the troubleshooting of economic sustainability problems of aquaculture enterprises. Although insect flour is currently a more environmentally friendly alternative compared with FM-in that the production of the raw material does not affect fish stocks-in light of both these results and the fact that FM and fish oils will maintain or increase their prices until the price of insect meal becomes significantly lower than the price of the FM that is currently used in aquaculture, the fish farm-to continue operating in the market-should find alternative solutions to reduce feeding costs, especially small-scale and specialized farms, such as the enterprise considered in our case study.

One solution may be to change the production scale of fish farms, which could reduce waste from an economic perspective, due to the possible presence of an increasing return to scale and the ability of the farm to increase its bargaining power with suppliers and organized large-scale distribution systems. The increasing of the production scale is affected by institutions and authorities' pivotal roles, which can actively promote training paths able to fill the lack of experience and knowledge of entrepreneurs, the lack of technologies used in fish production and extension services, and poor management. An entrepreneur's increasing professionalism could motivate the decision to extend the production scale and risk making new investments in the farm.

More generally, however, the high price related to insect meal would today limit the economic performance of most aquaculture farms, including large-scale farms. This is because the current insect meal and food production are not sufficient to ensure a constant supply. Several small- and medium-sized European start-up companies have emerged in recent years, but the major constraint limiting their growth is legislative barriers [49]. A recent report drawn up by the market and consulting firm Arcluster [50] estimates that the animal insect production market is worth half a billion dollars, with a growth forecast of over $\$ 1$ billion by 2022, meaning that insect feed could account for up to $3 \%$ of the entire production of the feed market within the next 4 years.

On the other hand, revenue streams are directly linked to the market price of European sea bass, and the final price of the fish does not reflect the rising price of feeding costs [13,14]. However, there is an ever-increasing demand for improving standards of quality and assurance in the sustainability process of fish production [1], and consumers are willing to pay a sustainability market price. Indeed, such consumers are less sensitive to price and thus are more willing to pay a premium for products that embody social and environmental attributes.

The use of insect meal in fish feed responds to such requirements, and recent research has shown a satisfactory level of its acceptance [30,37,51-54]. In this study, we did not simulate the economic effects related to a possible fish price increase derived from the introduction of insect meal due to the lack of empirical evidence that confirms this possibility. However, as such, consumers sensitive to the problem of the environmental sustainability of fishing could be willing to pay more for this type of fish. Also, because consumers afford great importance to the country of origin of fish [55], considering 
domestic fish to be of higher quality than imported fish [56,57], a local aquaculture farm will benefit from a more significant advantage and, therefore, could propose a higher sales price. A further solution could be the introduction of eco-labels, because, as suggested by previous research, their adoption can justify a premium price for food products [58]. The quality and the attention to the environment, along with certification standards, can generate increased confidence in consumers regarding the environmental responsibility and food safety of aquaculture products [59], further increasing the demand for such products.

Another aspect of interest is the consumer propensity to consume fish on the basis of, among other reasons, the attribution of positive health benefits and nutritional beliefs [60] and their disinclination to do in the case of a suspected health risk or the lack of information on the selection and preparation of fish [37]. Even in this instance, institutions and authorities' contributions can be useful for increasing consumer knowledge [61] and pushing them to search for high-quality products and to pay a premium to have them. Given the power of consumers to determine the success or failure of the use of insect meal, their awareness about the benefits of eating fish products derived from fish farms and the absence of risk related to eating fish fed with insects is crucial to encouraging both economic and environmental sustainability.

Finally, to better respond to future challenges and support the aquaculture sector and decisionmakers, more research in this field is required to improve knowledge on this issue. Future research could test the economic effects on the aquafarm cost structure of the use of other eco-friendly fish feed (i.e., other species of insects, poultry meal, or feeds derived from circular economy processes) both in sea bass production and that of other fish species, evaluating the effects by taking into account the different FCRs. Moreover, future research could investigate the use not only of the protein part of insects, but also of other "products" with high added value [see 6]. In other words, researchers could investigate not only using insects as a protein source, but also as "additives" (small quantities), able to modulate microbiota and in general to affect animal health (i.e., oil for antibacterial properties and chitin for pharmaceutical properties and immunostimulants, as well as anti-microbial peptides) [62].

Although it has some limitations (being based on simulations, only on sea bass production, and on a case study approach), this study is the first to attempt to explore the inclusion of insect meal in fish farming from an economic perspective. It shows that, in the future, the economic dimension of sustainability must go hand in hand with the environmental one, which is an essential condition pursuant to Goal 14 of the Sustainable Development Goals of 2030.

Author Contributions: Conceptualization, B.A., R.F., F.A.M. and P.P.; methodology, B.A., F.A.M.; software, B.A., F.A.M.; validation, B.A., R.F., F.A.M., L.G., and P.P.; formal analysis, B.A., F.A.M.; investigation, B.A., F.A.M.; data curation, B.A., L.G., F.A.M.; writing-original draft preparation, B.A., L.G., F.A.M.; writing-review and editing, B.A., R.F., L.G., F.A.M. and P.P.; supervision, R.F., P.P.; project administration, P.P.; funding acquisition, P.P.

Funding: This paper is carried out from the research project "Fine Fide for Fish-4F" granted by the AGER Consortium.

Conflicts of Interest: The authors declare no conflict of interest. The funders had no role in the design of the study; in the collection, analyses, or interpretation of data; in the writing of the manuscript; and in the decision to publish the results.

\section{Appendix A}

Cost-volume-profit (CVP) analysis was used to determine the feeding cost required to achieve the target profit and revenue. CVP analysis is a method of cost accounting that looks at the impact that varying levels of costs and volume have on the operating profit and allows for the determination of the breakeven point for different sales volumes and cost structures. The CVP makes several assumptions, including that the sales price, fixed costs, and variable cost per unit are constant. Running CVP analysis involves using several equations for price, cost, and other variables.

The CVP formula can be used to calculate, for example, the sales volume needed to cover costs or the variable costs and breakeven point (in accordance with the unknown variable). 
The basic formula is quite simple:

$$
\text { Profit }=\text { Total revenue }- \text { Total costs }
$$

Profit $=$ Selling price $\times$ Number of unit - Total fixed costs - Unit variable cost $\times$ Number of unit

In this case, the total fixed costs (TFC) account for the wages and salaries (WS), the depreciation of capital (DC), and the taxes (TX), whereas the variable costs account for the cost of energy and water (EW), fuel (FU), rent for boat (RB), livestock (LC), salaries (SA), other variable costs (OVC), interests (I), and feeding cost (FC).

Moreover, the sum of the LC, SA, FU, EX, RB, and OVC is identified with the acronym PVC (partial variable costs), and the \%FM is the percentage of pure FM in terms of the ratio between the FM and TM meal within the feed formula:

$$
\% \mathrm{FM}=\mathrm{FM}_{\mathrm{g} / \mathrm{kg}} / \text { Fish in feed formulation } \mathrm{g} / \mathrm{kg}
$$

Based on the assumption that (i) the FC is determined by the result of the multiplication of the price of $1 \mathrm{~kg}$ of feed formula (BP0) by the total feeding distributed (FD), and (ii) the interest rate (r) derives from the application of a coefficient equal to $4.54 \%$ of the PVC and FC, the average buy price (BP0) of the pure $\mathrm{FM}_{\mathrm{kg}}$ in the scenario $\mathrm{TM} 0 \%$ can be determined:

$$
\mathrm{BP0}=\frac{[\mathrm{TR}-\pi-\mathrm{TFC}-\mathrm{PVC}-\mathrm{r} \times(\mathrm{PVC})]}{\% \mathrm{FM} \times \mathrm{FD}+\mathrm{r} \times \% \mathrm{FM} \times \mathrm{FD}}
$$

where

$$
\pi=\mathrm{TR}-\mathrm{P} 0 \times \mathrm{FD} \times \% \mathrm{FM}-\mathrm{PVC}-\mathrm{I}-\mathrm{TFC}
$$

and

$$
\mathrm{I}=\mathrm{r} \times \mathrm{PVC}+\mathrm{BP} 0 \times \mathrm{r} \times \% \mathrm{FM} \times \mathrm{FD}
$$

Using the $\mathrm{BP} 0$ as a value that remains fixed regardless of the different percentage ratios between FM and TM meal, the second step consists of the estimation of the buy price per kg of feed formula (BPF) in all scenarios:

$$
\mathrm{BPF}=\mathrm{BP} 0 \times \% \mathrm{FM}+\mathrm{TM} \text { Price } 1 \times \% \mathrm{TM}
$$

Secondly, we estimated the buy price of TM meal that allows farmers to achieve in all scenarios (different prices of TM meal and different ratios between the TM meal and FM) the profit realized in scenario $\mathrm{TM} 0 \%(\mathrm{TMP} \pi)$. In other words, the buy price of TM meal that permits bearing the same feeding cost, employing a different quantity of FM, and ensuring the given level of production (given that all the scenarios show the same revenue) was obtained:

$$
\mathrm{TMP} \pi=\frac{[\mathrm{TR}-\pi-\mathrm{BP} 0 \times \mathrm{FD} \times \% \mathrm{FM}-\mathrm{PVC}-\mathrm{TXC}-\mathrm{r} \times \mathrm{PVC}]}{(\mathrm{FD} \times \% \mathrm{TM})+(\mathrm{r} \times \mathrm{FD} \times \% \mathrm{TM})}
$$

where the "\%TM" is, respectively, the percentages of pure TM meal in terms of the ratio between FM and TM meal within the formula

$$
\% \mathrm{TM}=\mathrm{TM}_{\mathrm{g} / \mathrm{kg}} / \text { Fish in feed formulation } \mathrm{g} / \mathrm{kg}
$$

Finally, an estimate was made on the buy price indifference related to theoretical scenarios characterized by any profit achievement (possible feed cost increase, to determine the profit equal to zero, i.e., TMP0):

$$
\mathrm{TMP} 0=\frac{[\mathrm{TR}-\mathrm{BP} 0 \times \mathrm{FD} \times \% \mathrm{FM})-\mathrm{PVC}-\mathrm{TFC}-\mathrm{r} \times \mathrm{PVC}]}{(\mathrm{FD} \times \% \mathrm{TM})+(\mathrm{r} \times \mathrm{FD} \times \% \mathrm{TM})}
$$




\section{References}

1. FAO. The State of World Fisheries and Aquaculture 2018-Meeting the Sustainable Development Goals; FAO: Rome, Italy, 2018.

2. Magalhães, R.; Sánchez-López, A.; Leal, R.S.; Martínez-Llorens, S.; Oliva-Teles, A.; Peres, H. Black soldier fly (Hermetia illucens) pre-pupae meal as a fish meal replacement in diets for European seabass (Dicentrarchus labrax). Aquaculture 2017, 476, 79-85. [CrossRef]

3. FAO. FAO and the SDGs. Indicators: Measuring up to the 2030 Agenda for Sustainable Development; FAO: Rome, Italy, 2017.

4. Volpe, J.P.; Gee, J.L.; Ethier, V.A.; Beck, M.; Wilson, A.J.; Stoner, J. Global Aquaculture Performance Index (GAPI): The first global environmental assessment of marine fish farming. Sustainability 2013, 5, 3976-3991. [CrossRef]

5. Bossier, P.; Ekasari, J. Biofloc technology application in aquaculture to support sustainable development goals. Microb. Biotechnol. 2017, 10, 1012-1016. [CrossRef] [PubMed]

6. Gasco, L.; Gai, F.; Maricchiolo, G.; Genovese, L.; Ragonese, S.; Bottari, T.; Caruso, G. Fishmeal alternative protein sources for aquaculture feeds. In Feeds for the Aquaculture Sector; Springer: Berlin/Heidelberg, Germany, 2018; pp. 1-28.

7. Asche, F.; Roll, K.H.; Tveterås, S. Future Trends in Aquaculture: Productivity Growth and Increased Production. In Aquaculture in the Ecosystem; Springer: Dordrecht, The Netherlands, 2008; pp. 271-292. ISBN 978-1-4020-6809-6.

8. Van Huis, A.; Van Itterbeeck, J.; Klunder, H.; Mertens, E.; Halloran, A.; Muir, G.; Vantomme, P. Edible Insects: Future Prospects for Food and Feed Security; Food and Agriculture Organization of the United nations (FAO): Rome, Italy, 2013; ISBN 92-5-107596-4.

9. Tunde, A.B.; Kuton, M.; Oladipo, A.A.; Olasunkanmi, L.H. Economic analyze of costs and return of fish farming in Saki-East Local Government Area of Oyo State, Nigeria. J. Aquac. Res. Dev. 2015, 6, 1.

10. Henry, M.; Gasco, L.; Piccolo, G.; Fountoulaki, E. Review on the use of insects in the diet of farmed fish: Past and future. Anim. Feed Sci. Technol. 2015, 203, 1-22. [CrossRef]

11. Dickson, M.; Nasr-Allah, A.; Kenawy, D.; Kruijssen, F. Increasing fish farm profitability through aquaculture best management practice training in Egypt. Aquaculture 2016, 465, 172-178. [CrossRef]

12. Kleih, U.; Linton, J.; Marr, A.; Mactaggart, M.; Naziri, D.; Orchard, J.E. Financial services for small and medium-scale aquaculture and fisheries producers. Mar. Policy 2013, 37, 106-114. [CrossRef]

13. Shaalan, M.; El-Mahdy, M.; Saleh, M.; El-Matbouli, M. Aquaculture in Egypt: Insights on the Current Trends and Future Perspectives for Sustainable Development. Rev. Fish. Sci. Aquac. 2018, 26, 99-110. [CrossRef]

14. Adwan, O.M.A. Analyzing Fish Farming System in the Jordan Valley Comparative study. J. Soc. Sci. COESRJ-JSS 2017, 6, 827-832.

15. Meneguz, M.; Schiavone, A.; Gai, F.; Dama, A.; Lussiana, C.; Renna, M.; Gasco, L. Effect of rearing substrate on growth performance, waste reduction efficiency and chemical composition of black soldier fly (Hermetia illucens) larvae. J. Sci. Food Agric. 2018, 98, 5776-5784. [CrossRef]

16. Belforti, M.; Gai, F.; Lussiana, C.; Renna, M.; Malfatto, V.; Rotolo, L.; De Marco, M.; Dabbou, S.; Schiavone, A.; Zoccarato, I. Tenebrio molitor meal in rainbow trout (Oncorhynchus mykiss) diets: Effects on animal performance, nutrient digestibility and chemical composition of fillets. Ital. J. Anim. Sci. 2015, 14, 4170. [CrossRef]

17. Gasco, L.; Henry, M.; Piccolo, G.; Marono, S.; Gai, F.; Renna, M.; Lussiana, C.; Antonopoulou, E.; Mola, P.; Chatzifotis, S. Tenebrio molitor meal in diets for European sea bass (Dicentrarchus labrax L.) juveniles: Growth performance, whole body composition and in vivo apparent digestibility. Anim. Feed Sci. Technol. 2016, 220, 34-45. [CrossRef]

18. Sánchez-Muros, M.; Haro, C.; Sanz, A.; Trenzado, C.; Villareces, S.; Barroso, F. Nutritional evaluation of Tenebrio molitor meal as fishmeal substitute for tilapia (Oreochromis niloticus) diet. Aquac. Nutr. 2016, 22, 943-955. [CrossRef]

19. Roncarati, A.; Gasco, L.; Parisi, G.; Terova, G. Growth performance of common catfish (Ameiurus melas Raf.) fingerlings fed mealworm (Tenebrio molitor) diet. J. Insects Food Feed 2015, 1, 233-240. [CrossRef] 
20. Henry, M.A.; Gasco, L.; Chatzifotis, S.; Piccolo, G. Does dietary insect meal affect the fish immune system? The case of mealworm, Tenebrio molitor on European sea bass, Dicentrarchus labrax. Dev. Comp. Immunol. 2018, 81, 204-209. [CrossRef]

21. Pascucci, S.; Dentoni, D.; Mitsopoulos, D. The perfect storm of business venturing? The case of entomology-based venture creation. Agric. Food Econ. 2015, 3, 9. [CrossRef]

22. International Platform of Insects for Food and Feed (IPIFF). The European Insect Sector Today: Challenges, Opportunities and Regulatory Landscape; IPIFF: Brussels, Belgium, 2018.

23. Brabant Development Company. Insectenkweek: Kleine Sector, Grote Kansen; Brabant Development Company: Tilburg, Netherlands, 2016.

24. FEAP. European Aquacolture Production Report 2007-2015; FEAP: Liege, Belgium, 2016.

25. Iaconisi, V.; Bonelli, A.; Pupino, R.; Gai, F.; Parisi, G. Mealworm as dietary protein source for rainbow trout: Body and fillet quality traits. Aquaculture 2018, 484, 197-204. [CrossRef]

26. Oliva-Teles, A.; Enes, P.; Peres, H. Replacing fishmeal and fish oil in industrial aquafeeds for carnivorous fish. In Feed and Feeding Practices in Aquaculture; Davis, A.D., Ed.; Elsevier: Cambridge, UK, 2015; pp. 203-233.

27. Gai, F.; Gasco, L.; Daprà, F.; Palmegiano, G.B.; Sicuro, B. Enzymatic and Histological Evaluations of Gut and Liver in Rainbow Trout, Oncorhynchus mykiss, Fed with Rice Protein Concentrate-based Diets. J. World Aquac. Soc. 2012, 43, 218-229. [CrossRef]

28. Howe, E.R.; Simenstad, C.A.; Toft, J.D.; Cordell, J.R.; Bollens, S.M. Macroinvertebrate prey availability and fish diet selectivity in relation to environmental variables in natural and restoring north San Francisco bay tidal marsh channels. San Franc. Estuary Watershed Sci. 2014, 12, 1-46. [CrossRef]

29. Van Huis, A. Potential of insects as food and feed in assuring food security. Annu. Rev. Entomol. 2013, 58, 563-583. [CrossRef]

30. Makkar, H.P.; Tran, G.; Heuzé, V.; Ankers, P. State-of-the-art on use of insects as animal feed. Anim. Feed Sci. Technol. 2014, 197, 1-33. [CrossRef]

31. Ghosh, S.; Lee, S.-M.; Jung, C.; Meyer-Rochow, V. Nutritional composition of five commercial edible insects in South Korea. J. Asia-Pac. Entomol. 2017, 20, 686-694. [CrossRef]

32. De Marco, M.; Martínez, S.; Hernandez, F.; Madrid, J.; Gai, F.; Rotolo, L.; Belforti, M.; Bergero, D.; Katz, H.; Dabbou, S. Nutritional value of two insect larval meals (Tenebrio molitor and Hermetia illucens) for broiler chickens: Apparent nutrient digestibility, apparent ileal amino acid digestibility and apparent metabolizable energy. Anim. Feed Sci. Technol. 2015, 209, 211-218. [CrossRef]

33. Liu, W.; Wei, M.; Liu, G. Bioactive compounds from insects and its development perspective. Food Sci. Technol. 2005, 1, 16.

34. Rumpold, B.A.; Schlüter, O.K. Potential and challenges of insects as an innovative source for food and feed production. Innov. Food Sci. Emerg. Technol. 2013, 17, 1-11. [CrossRef]

35. Siemianowska, E.; Kosewska, A.; Aljewicz, M.; Skibniewska, K.A.; Polak-Juszczak, L.; Jarocki, A.; Jedras, M. Larvae of mealworm (Tenebrio molitor L.) as European novel food. Agric. Sci. 2013, 4, 287.

36. Khosravi, S.; Kim, E.; Lee, Y.-S.; Lee, S.-M. Dietary inclusion of mealworm (Tenebrio molitor) meal as an alternative protein source in practical diets for juvenile rockfish (Sebastes schlegeli): Mealworm meal in rockfish feed. Entomol. Res. 2018, 48, 214-221. [CrossRef]

37. Mancuso, T.; Baldi, L.; Gasco, L. An empirical study on consumer acceptance of farmed fish fed on insect meals: The Italian case. Aquac. Int. 2016, 24, 1489-1507. [CrossRef]

38. Veldkamp, T.; Bosch, G. Insects: A protein-rich feed ingredient in pig and poultry diets. Anim. Front. 2015, 5, $45-50$.

39. Yin, R.K. Case Study Research: Design and Methods; SAGE Publications: Thousand Oaks, CA, USA, 2013; ISBN 978-1-4833-2224-7.

40. Flick, U. An Introduction to Qualitative Research; Sage: Thousand Oaks, CA, USA, 2009; ISBN 1-4462-9772-1.

41. Glasser, B.; Strauss, A. The Discovery of Grounded Theory: Strategies for Qualitative Research; Adline De Gruyter: Hawthorne, NY, USA, 1967.

42. Eisenhardt, K.M. Building theories from case study research. Acad. Manag. Rev. 1989, 14, 532-550. [CrossRef]

43. Rana, K.J.; Siriwardena, S.; Hasan, M.R. Impact of Rising Feed Ingredient Prices on Aquafeeds and Aquaculture Production; Food and Agriculture Organization of the United Nations (FAO): Rome, Italy, 2009; ISBN 92-5-106422-9. 
44. Wilson, R.P. Protein and aminoacids. In Fish Nutrition; Academic Press: Cambridge, MA, USA, 2002; ISBN 978-0-08-049492-0.

45. Riddick, E.W. Insect protein as a partical replacement of fishmeal in the diets of juvenile fish and crustaceans. In Mass Production of Beneficial Organisms; Elsevier: Amsterdam, The Netherlands, 2014; pp. 565-582.

46. Forleo, M.B.; Romagnoli, L.; Palmieri, N.; Di Nocera, A. Assessing the efficiency of aquaculture cooperatives. A country case study. Econ. Agro-Aliment. 2018, 20, 205-220. [CrossRef]

47. Nidumolu, R.; Prahalad, C.K.; Rangaswami, M.R. Why sustainability is now the key driver of innovation. Harv. Bus. Rev. 2009, 87, 56-64.

48. Van Huis, A.; Oonincx, D.G.A.B. The environmental sustainability of insects as food and feed. A review. Agron. Sustain. Dev. 2017, 37, 43. [CrossRef]

49. Lähteenmäki-Uutela, A.; Hénault-Ethier, L.; Marimuthu, S.; Talibov, S.; Allen, R.; Nemane, V.; Vandenberg, G.; Józefiak, D. The impact of the insect regulatory system on the insect marketing system. J. Insects Food Feed 2018, 4, 187-198. [CrossRef]

50. Arcluster. Insect Feed Market (2017-2022); Arcluster: Singapore, 2017.

51. Hénault-Ethier, L.; Dussault, M.; Cabrera, P.; Lefebvre, B.; Taillefer, S.; Deschamps, M.-H.; Vandenberg, G. Les insectes au service de l'humain pour la gestion des résidus organiques. Vecteur Environ. 2017, 50, 46-53.

52. Popoff, M.; MacLeod, M.; Leschen, W. Attitudes towards the use of insect-derived materials in Scottish salmon feeds. J. Insects Food Feed 2017, 3, 131-138. [CrossRef]

53. Stamer, A. Insect proteins-A new source for animal feed: The use of insect larvae to recycle food waste in high-quality protein for livestock and aquaculture feeds is held back largely owing to regulatory hurdles. EMBO Rep. 2015, 16, 676-680. [CrossRef] [PubMed]

54. Verbeke, W.; Spranghers, T.; De Clercq, P.; De Smet, S.; Sas, B.; Eeckhout, M. Insects in animal feed: Acceptance and its determinants among farmers, agriculture sector stakeholders and citizens. Anim. Feed Sci. Technol. 2015, 204, 72-87. [CrossRef]

55. Claret, A.; Guerrero, L.; Aguirre, E.; Rincón, L.; Hernández, M.D.; Martínez, I.; Peleteiro, J.B.; Grau, A.; Rodríguez-Rodríguez, C. Consumer preferences for sea fish using conjoint analysis: Exploratory study of the importance of country of origin, obtaining method, storage conditions and purchasing price. Food Qual. Prefer. 2012, 26, 259-266. [CrossRef]

56. Mauracher, C.; Tempesta, T.; Vecchiato, D. Consumer preferences regarding the introduction of new organic products. The case of the Mediterranean sea bass (Dicentrarchus labrax) in Italy. Appetite 2013, 63, 84-91. [CrossRef]

57. Stefani, G.; Scarpa, R.; Cavicchi, A. Exploring consumer's preferences for farmed sea bream. Aquac. Int. 2012, 20, 673-691. [CrossRef]

58. Zhou, G.; Hu, W.; Huang, W. Are Consumers Willing to Pay More for Sustainable Products? A Study of Eco-Labeled Tuna Steak. Sustainability 2016, 8, 494. [CrossRef]

59. Washington, S.; Ababouch, L. Private Standards and Certification in Fisheries and Aquaculture; FAO Fisheries and Aquaculture Technical Paper No. 553; FAO: Rome, Italy, 2011.

60. Carlucci, D.; Nocella, G.; De Devitiis, B.; Viscecchia, R.; Bimbo, F.; Nardone, G. Consumer purchasing behaviour towards fish and seafood products. Patterns and insights from a sample of international studies. Appetite 2015, 84, 212-227. [CrossRef] [PubMed]

61. Materia, V.C.; Cavallo, C. Insetti per l'alimentazione umana: Barriere e drivers per l'accettazione da parte dei consumatori. Riv. Econ. Agrar. 2015, 70, 139-161.

62. Gasco, L.; Finke, M.; Van Huis, A. Can diets containing insects promote animal health? J Insects Food Feed 2018, 4, 1-4. [CrossRef]

(C) 2019 by the authors. Licensee MDPI, Basel, Switzerland. This article is an open access article distributed under the terms and conditions of the Creative Commons Attribution (CC BY) license (http:/ / creativecommons.org/licenses/by/4.0/). 